\title{
Compatibility Studies of Cladding Candidates and Advanced Low-Cr Superalloys in Molten $\mathrm{NaCl}-\mathrm{MgCl}_{2}$
}

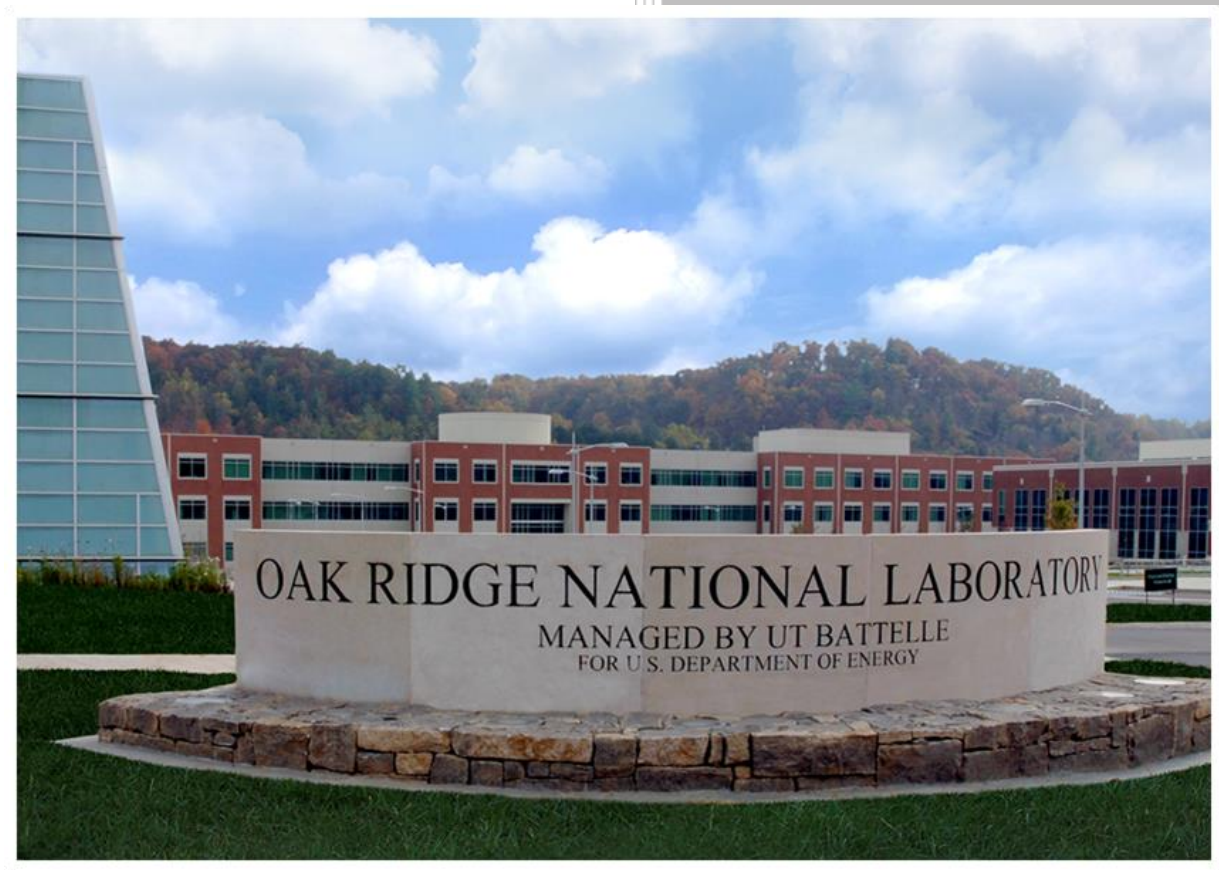

\section{Approved for public release. Distribution is unlimited}
S. S. Raiman
G. Muralidharan
R. T. Mayes
J. M. Kurley

April 2019 


\title{
DOCUMENT AVAILABILITY
}

Reports produced after January 1, 1996, are generally available free via US Department of Energy (DOE) SciTech Connect.

Website www.osti.gov

Reports produced before January 1, 1996, may be purchased by members of the public from the following source:

\author{
National Technical Information Service \\ 5285 Port Royal Road \\ Springfield, VA 22161 \\ Telephone 703-605-6000 (1-800-553-6847) \\ TDD 703-487-4639 \\ Fax 703-605-6900 \\ E-mail info@ntis.gov \\ Website http://classic.ntis.gov/
}

Reports are available to DOE employees, DOE contractors, Energy Technology Data Exchange representatives, and International Nuclear Information System representatives from the following source:

Office of Scientific and Technical Information

PO Box 62

Oak Ridge, TN 37831

Telephone 865-576-8401

Fax 865-576-5728

E-mail reports@osti.gov

Website http://www.osti.gov/contact.html

This report was prepared as an account of work sponsored by an agency of the United States Government. Neither the United States Government nor any agency thereof, nor any of their employees, makes any warranty, express or implied, or assumes any legal liability or responsibility for the accuracy, completeness, or usefulness of any information, apparatus, product, or process disclosed, or represents that its use would not infringe privately owned rights. Reference herein to any specific commercial product, process, or service by trade name, trademark, manufacturer, or otherwise, does not necessarily constitute or imply its endorsement, recommendation, or favoring by the United States Government or any agency thereof. The views and opinions of authors expressed herein do not necessarily state or reflect those of the United States Government or any agency thereof. 
Materials Science and Technology Division

\title{
Compatibility Studies of Cladding Candidates and Advanced Low-Cr Nickel Superalloys in Molten $\mathrm{NaCl}-\mathrm{MgCl}_{2}$
}

\author{
Author(s) \\ Stephen S. Raiman \\ Govindarajan Muralidharan \\ Richard T. Mayes \\ J. Matt Kurley
}

Date Published: 4/15/2019

Prepared by

OAK RIDGE NATIONAL LABORATORY

Oak Ridge, TN 37831-6283

managed by

UT-BATTELLE, LLC

for the

US DEPARTMENT OF ENERGY

under contract DE-AC05-00OR22725 


\section{CONTENTS}

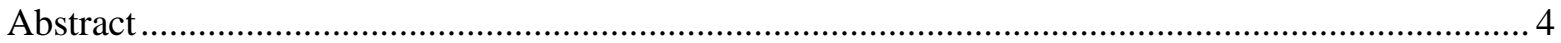

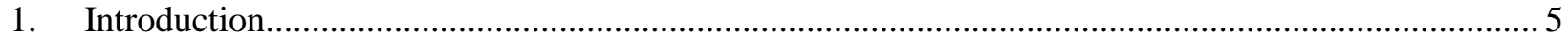

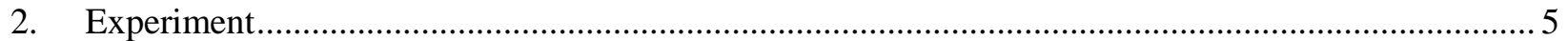

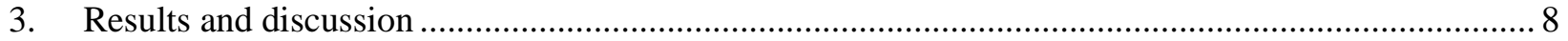

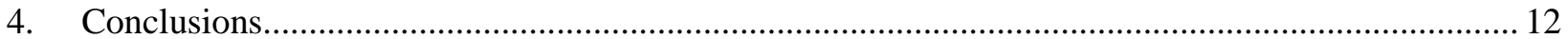

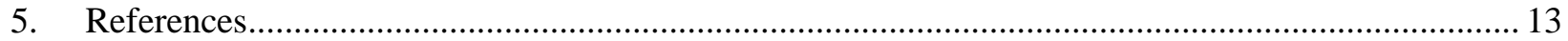




\begin{abstract}
To mitigate corrosion of salt-facing components in molten salts, the use of cladding on structural materials is under consideration. A second approach is the use of low-Cr alloys similar to Alloy-N, but with improved properties. To examine the compatibility of candidate materials for these purposes, potential cladding materials, ORNL-developed low-Cr nickel alloys, and commercial alloys were exposed to static $\mathrm{NaCl}-\mathrm{MgCl}_{2}(63-37 \mathrm{~mol} \%)$ at $700^{\circ}$ for $500 \mathrm{~h}$. Alloys 617 and $800 \mathrm{H}$ had low corrosion rates compared to alloy-N and 316L stainless steel. The ORNL developed alloys had varying corrosion performance, all losing less than $10 \mathrm{mg} / \mathrm{cm}^{2}$, but did not significantly outperform commercial alloys with higher $\mathrm{Cr}$ contents. Cladding candidates tungsten, TZM, and tantalum had very low mass change, while alloy-200 samples (99\% Ni) had by far the highest mass change, $20-25 \mathrm{mg} / \mathrm{cm}^{2}$.
\end{abstract}




\section{INTRODUCTION}

Several molten salt reactor developers have proposed chloride salts as fuel media and/or heat transfer media. Despite their advantages, which include low cost and large solvated fuel capacity, at this stage in their development chloride salts are more corrosive to the most common MSR structural materials than are fluoride salts. This may be due to the relative lack of knowledge about purification of chloride salts when compared to fluoride salts. Still, even if purification techniques for chloride salts improve drastically and chloride salts proposed for use in MSRs become less aggressive,mitigation of corrosion will still remain essential.

To address material issues in chloride-based MSRs, two solutions are proposed. First, the use of advanced nickel superalloys. Previous work has shown Alloy-N resists corrosion in fluoride salts ${ }^{1-3}$ including in the MSRE, and may similarly resist corrosion in chloride salts. Several candidate nickel alloys are proposed which are similar in composition to alloy-N (low $\mathrm{Cr}$, with Mo addition) but with improvements in high temperature strength and creep resistance.

Another approach is the use of corrosion resistant materials as cladding on salt-facing structural materials. This approach allows the use of code-qualified structural materials for mechanical strength, with the advantage of specially-chosen materials for corrosion resistance on salt-facing surfaces. This method has several complications, including weldability and compatibility between clad and structural materials.

The objective of this work is to describe initial salt-compatibility testing of cladding material candidates and advanced nickel superalloys in molten chloride salts. The experimental procedure is described, along with preliminary results, with a full characterization of exposed samples to come in a later work.

\section{EXPERIMENT}

Candidate materials were selected from two categories. First, a set of nickel superalloys (referenced in this work as alloys M48-M52) developed at ORNL for use with molten salts. Compositions of the alloys are not disclosed due to the terms of a Technology Commercialization Fund project with Haynes International. While individual compositions of the alloys are not disclosed, they were all based on US patents filed by G. Muralidharan and D. Holcomb. ${ }^{4-6}$ The alloys are all nickel-base alloys with 6-9 Cr. Alloy M49 is a $\gamma$ ' strengthened, while the others are solid-solution strengthened. The alloys were developed to offer corrosion resistance similar to Alloy-N, but with enhanced high temperature strength and improved creep resistance.

The second set of samples are candidate materials for use as cladding in MSRs. The materials tested - tungsten, nickel, tantalum, and TZM (99\% Mo) - were chosen due to their calculated thermodynamic stability in molten chloride salts ${ }^{7}$. Other concerns such as mechanical properties and weldability are not discussed in this report, but are important issues which must be addressed if these materials are going to be acceptable for use as salt-facing claddings.

For comparison, commercial heats of select alloys were also exposed to the same conditions: Alloy-N, 316L stainless steel, Inconel-617, and Alloy-800H. The nominal compositions of the commercial alloys are given in table 1 .

Candidate materials were cut into coupons measuring $12.7 \times 6.4 \times 1.5 \mathrm{~mm}$, with a $1 \mathrm{~mm}$ hole. Two coupons of each of the following materials were prepared

1. 316 stainless steel

2. Alloy-N

3. Inconel-617

4. Alloy $800 \mathrm{H}$ 
5. M48

6. M49

7. M50

8. M51

9. M52

10. Nickel 200

11. TZM

12. Tantalum

13. Tungsten

Table 1. Nominal alloy compositions

\begin{tabular}{cccccc}
\hline \multirow{2}{*}{ Name } & \multicolumn{5}{c}{ Nominal composition, wt.\%* } \\
\cline { 2 - 6 } & $\mathrm{Fe}$ & $\mathrm{Ni}$ & $\mathrm{Cr}$ & $\mathrm{Mo}$ & Other \\
\hline 316L SS & 68 & 10 & 17 & 3 & \\
\hline Alloy N & 71 & 4 & 7 & 16 & \\
\hline Alloy 617 & 1 & 53 & 24 & 10 & 12 Co \\
\hline Nickel 200 & & 99 & & & \\
\hline TZM & \multicolumn{5}{c}{99} \\
\hline
\end{tabular}

Samples were exposed to molten $\mathrm{NaCl}-\mathrm{MgCl}_{2}$ in solid molybdenum capsules measuring 1" in diameter and 3" in length, with one sample per capsule. Samples were tethered to one endcap of the capsule which was welded to the capsule body. Each molybdenum "inner" capsule was enclosed within a stainless steel outer capsule to prevent air oxidation in the furnace. A schematic of the capsule design is shown in Figure 1, and photographs of representative capsules and a sample are shown in Figure 2.

To prepare the salts used for this study, ACS grade $\mathrm{NaCl}$ and $98 \%$ pure $\mathrm{MgCl}_{2}$ were purchased from Alfa Aesar. The $\mathrm{NaCl}$ was melted and sparged with $\mathrm{CCl}_{4}$ for 3 hours, argon for 30 minutes, argon with $4 \%$ hydrogen for 1 hour, and argon again for 30 minutes. The $\mathrm{MgCl}$ was purified with the carnalite method, in which the sale is mixed with $\mathrm{NH}_{4} \mathrm{Cl}$ in a $2: 1 \mathrm{MgCl}_{2}: \mathrm{NH}_{4} \mathrm{Cl}$ ratio, heated to $450^{\circ} \mathrm{C}$, and held at that temperature for two hours before heating to $750^{\circ} \mathrm{C}$, where it is held for one hour. The mixture was then sparged with $\mathrm{CCl}_{4}$ at $850^{\circ} \mathrm{C}$ for $35-40$ hours, followed by an argon sparge for 30 minutes. Following that, the mixture was sparged with argon-4\% hydrogen for 12-15 hours, followed by another argon sparge for 30 minutes. Lastly, the $\mathrm{NaCl}$ and $\mathrm{MgCl}_{2}$ were mixed together in the desired $63 / 37 \mathrm{NaCl} / \mathrm{MgCl}_{2}$ (molar) eutectic composition, heated to $850^{\circ} \mathrm{C}$, and sparged with argon for 30 minutes. Acid-base titration was used to assess the moisture content of the salts after purification, and oxide content was below the detection limit of approximately $1 \mathrm{ppm}$.

Each capsule was filled with $28 \mathrm{~g}$ of solid salt in a glove box, and lids were press-fit onto the open end of the capsules. The capsules were transported in vacuum to an electron-beam welder where they were removed from vacuum, placed in the welder, and pumped down to vacuum. The welder chamber was allowed to pump overnight before welding the lids shut. The molybdenum capsules were sealed in vacuum within stainless steel outer capsules for secondary containment. Graphite spacers were used to separate the inner and outer capsules.

The capsules were heated in a box furnace for 500 hours at $700^{\circ} \mathrm{C}$. After cooling, samples were removed from the capsules, and bathed in $50^{\circ} \mathrm{C}$ water for several hours to remove the salt. Samples were weighed for mass change with a Mettler Toledo model XP205 balance with an accuracy of $\pm 0.04 \mathrm{mg}$ $\left(<0.01 \mathrm{mg} / \mathrm{cm}^{2}\right)$. After weighing, samples were cross-sectioned and imaged optically with a Leica MEF4A microscope. 


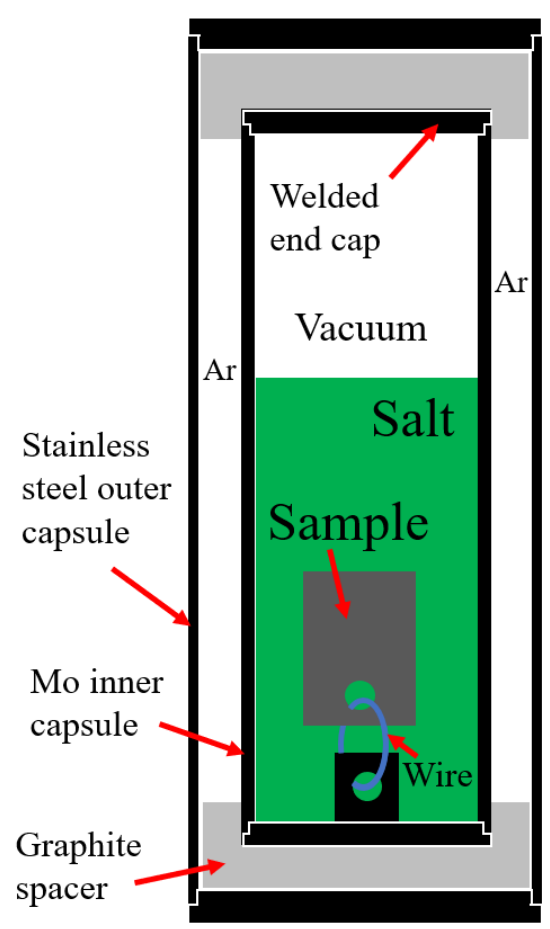

Figure 1. A schematic diagram of a filled capsule

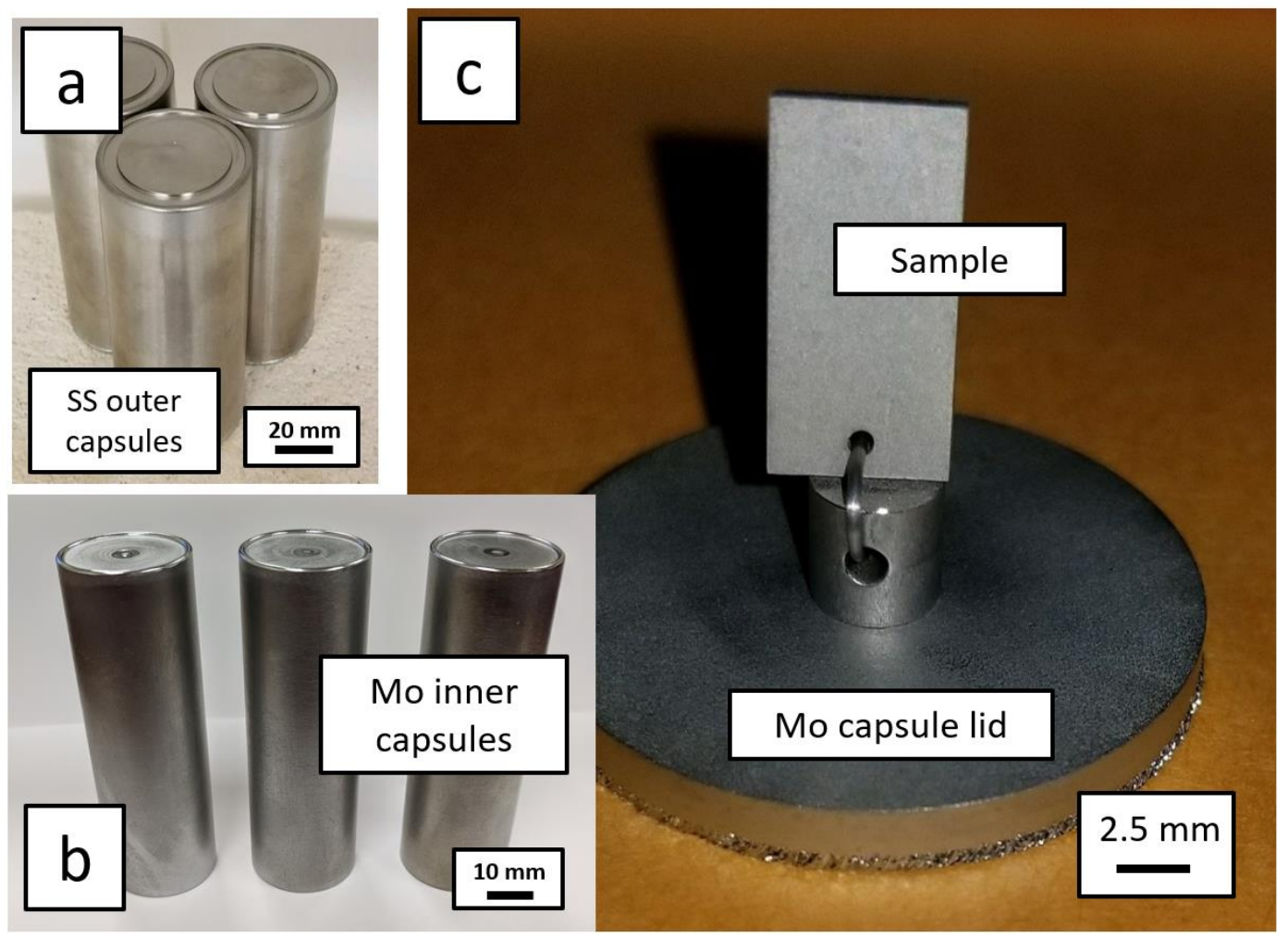

Figure 2. Photographs of (a) stainless steel outer capsules, (b) molybdenum inner capsules, and (c) a sample tethered to a molybdenum capsule endcap 


\section{RESULTS AND DISCUSSION}

Light micrographs of the samples after exposure are shown in Figure 3. Mass change results are shown in Figure 4. Among commercial alloys, Inconel-617 and alloy-800H performed better than alloy-N and $316 \mathrm{SS}$. However, the relatively poor high temperature strength of alloy- $800 \mathrm{H}$ may disqualify it as a structural material for MSRs. The high cobalt concentration of Inconel-617 may disqualify it as a core material for MSRs.

Among the ORNL developed nickel based superalloys, M49 and M52 performed the best. All the cladding materials candidates performed well except nickel-200 which lost the most mass of any material by a large margin. This is surprising because thermodynamic calculations suggest that nickel should be relatively stable in both chloride and fluoride salts ${ }^{7}$. Further work will be necessary to investigate the cause of the high corrosion rate observed on nickel-200. Both TZM and tungsten performed very well, but both have concerns regarding workability and weldability.
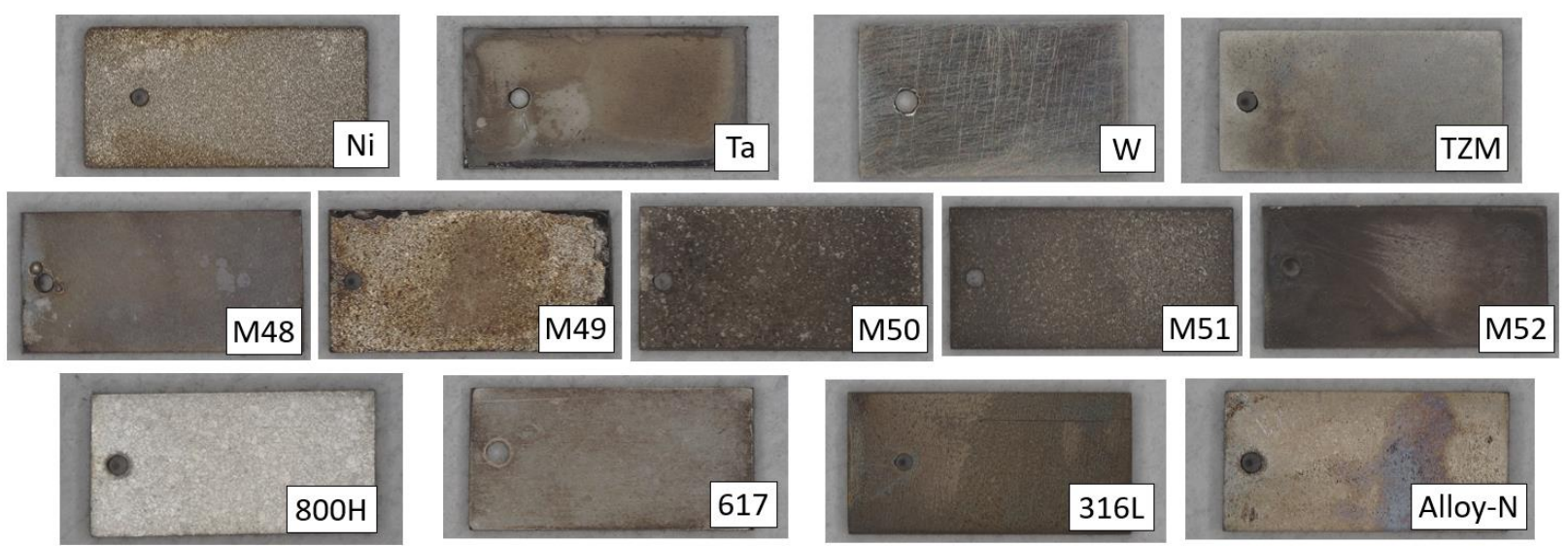

Figure 3. Light micrographs of corrosion coupons after exposure to $\mathrm{NaCl}-\mathrm{MgCl}_{2}$ for $500 \mathrm{~h}$ at $700^{\circ} \mathrm{C}$. Samples were sonicated in $40^{\circ} \mathrm{C}$ water to remove residual salt before being photographed. 


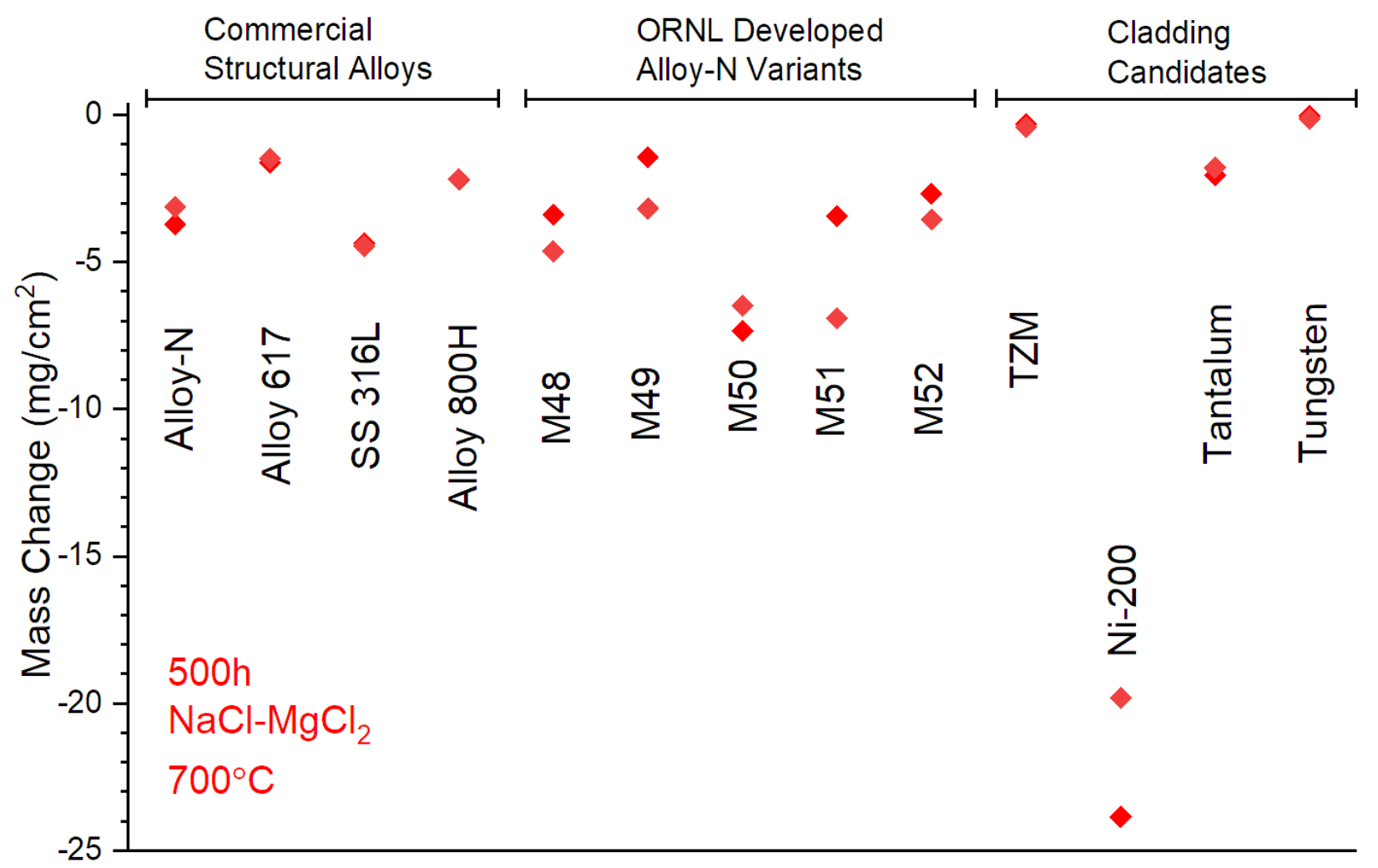

Figure 4. Mass change of commercial alloys, nickel superalloys, and cladding candidates exposed to $\mathrm{NaCl}-\mathrm{MgCl}_{2}$ for $500 \mathrm{~h}$ at $700^{\circ} \mathrm{C}$.

Figures 5-11 show representative optical micrographs of the samples cross-sections after exposure. Despite the very similar mass loss measurements for both Alloy-617 samples, the cross sections show a very different morphology. The 316L samples also showed different behavior - sample A had severe attack and a crack-like attack. Sample B still shows signs of severe attack, but the result is a rough boundary free of jagged edges or cracks. Internal attack along apparent grain boundaries is visible on sample M49 B, while M49A displays a more uniform attack along the surface.

Consistent with the mass change results, $\mathrm{Ni}$ appears heavily attacked, leaving behind an uneven surface. No pores are visible, likely due to the nearly single-element composition of the alloy 


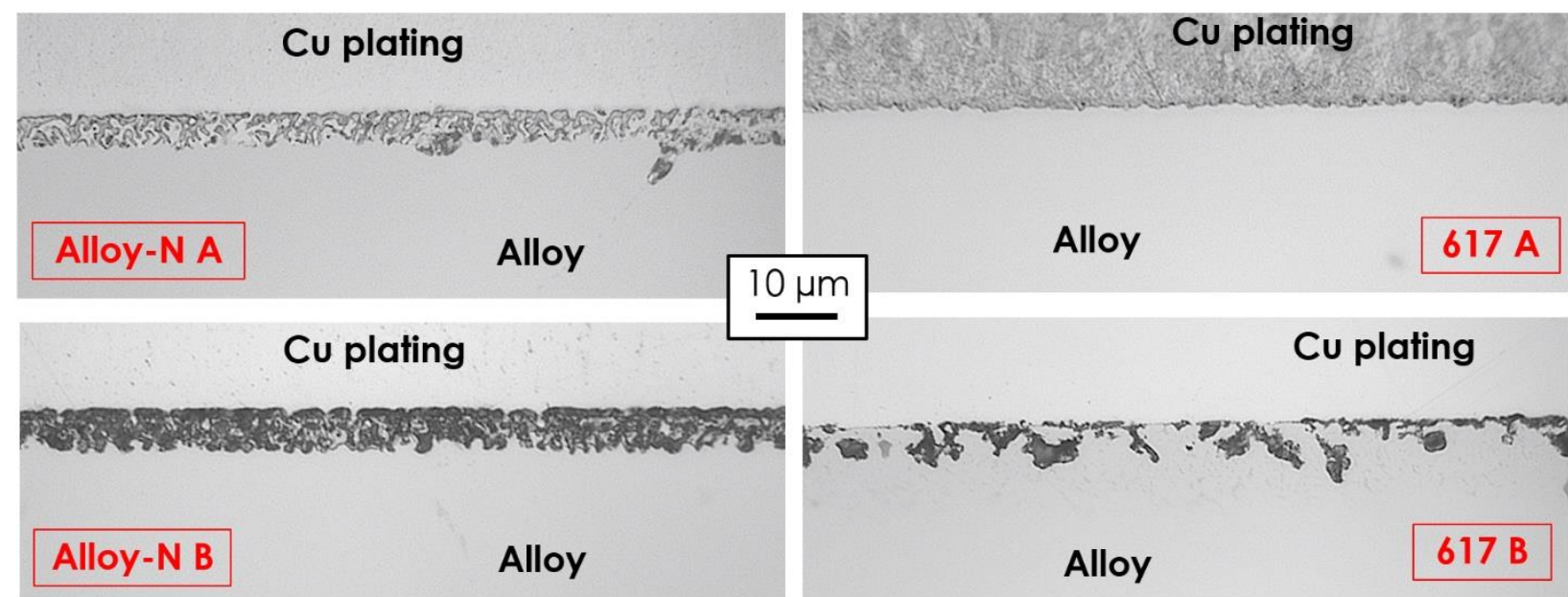

Figure 5. Light micrographs of Alloy-N and Alloy 617 cross-sections after exposure to NaCl$\mathrm{MgCl}_{2}$ for $500 \mathrm{~h}$ at $700^{\circ} \mathrm{C}$.

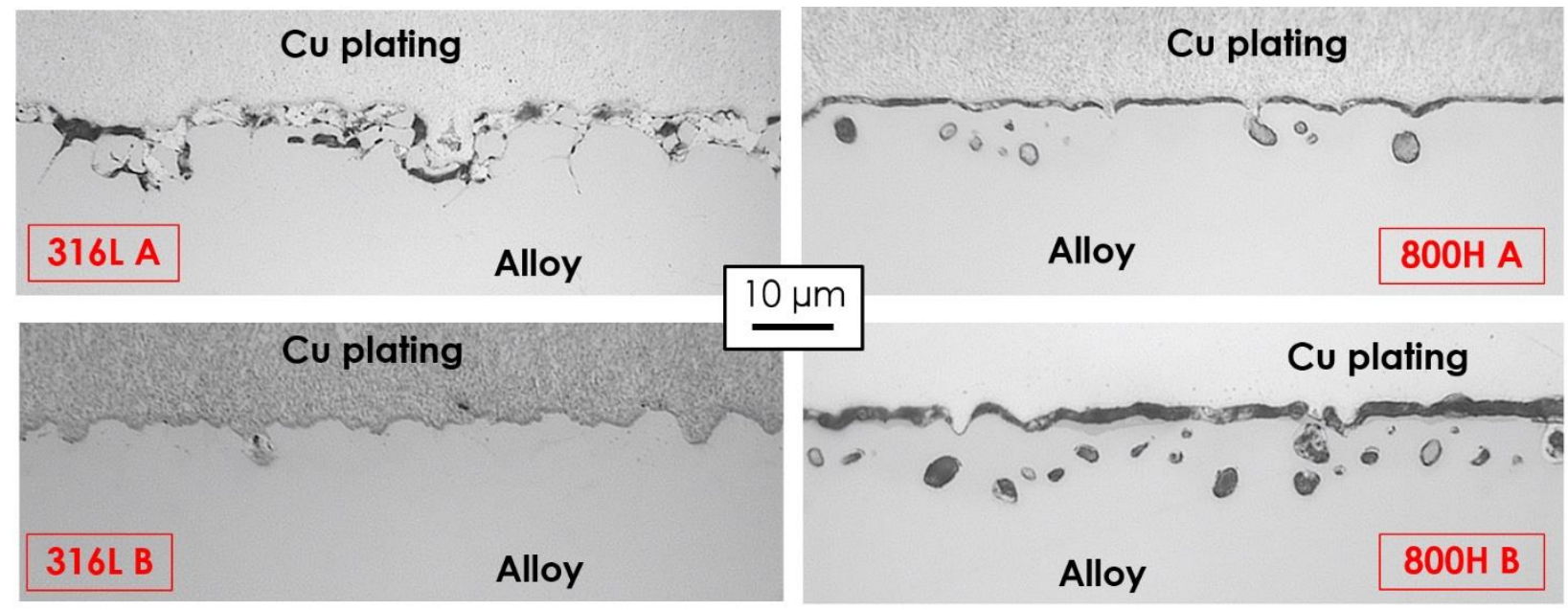

Figure 6. Light micrographs of 316L and Alloy $800 \mathrm{H}$ cross-sections after exposure to NaCl$\mathrm{MgCl}_{2}$ for $500 \mathrm{~h}$ at $700^{\circ} \mathrm{C}$. 


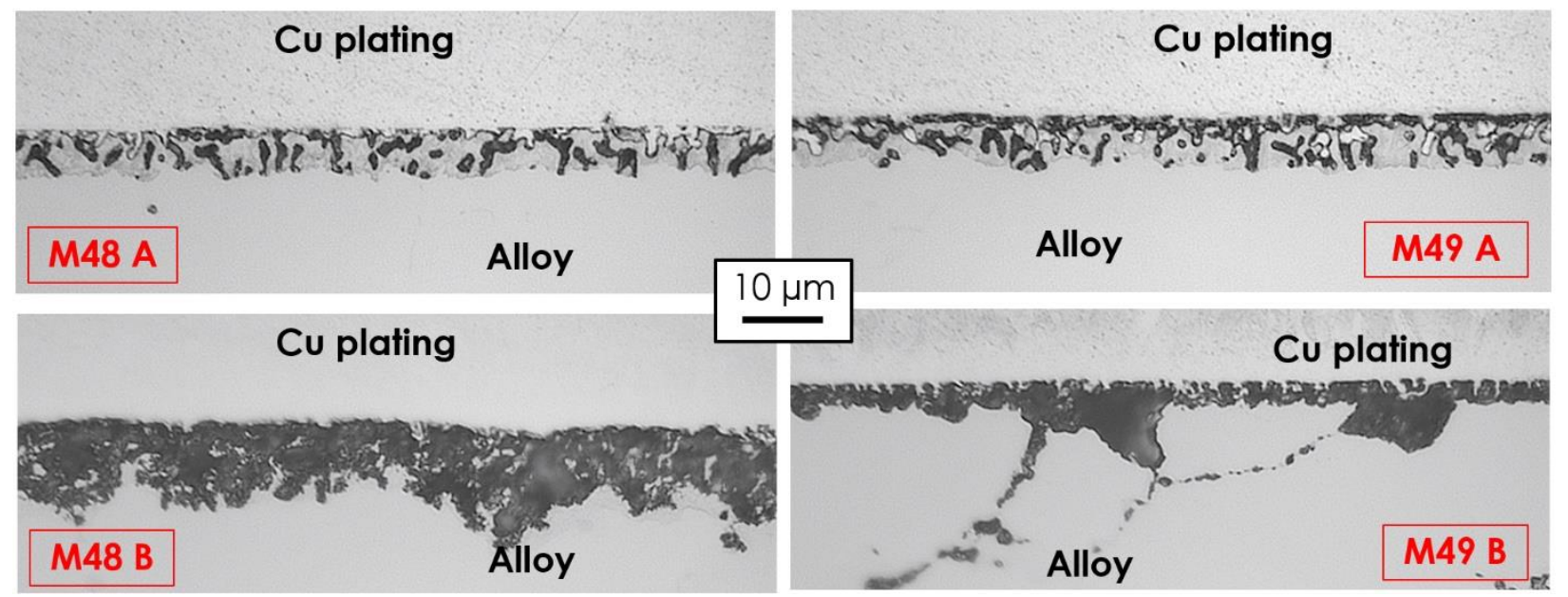

Figure 7. Light micrographs of Alloy M48 and M49 cross-sections after exposure to NaCl$\mathrm{MgCl}_{2}$ for $500 \mathrm{~h}$ at $700^{\circ} \mathrm{C}$.

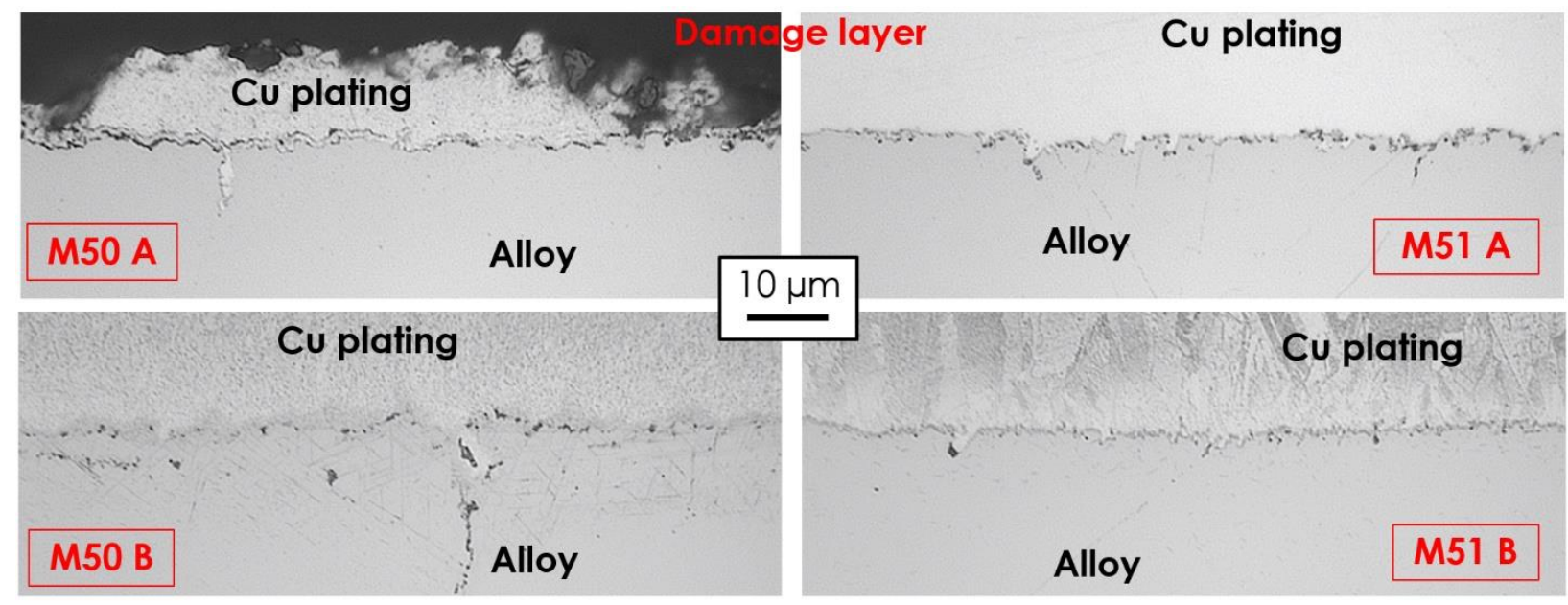

Figure 8. Light micrographs of Alloy M50 and M51 cross-sections after exposure to NaCl$\mathrm{MgCl}_{2}$ for $500 \mathrm{~h}$ at $700^{\circ} \mathrm{C}$.

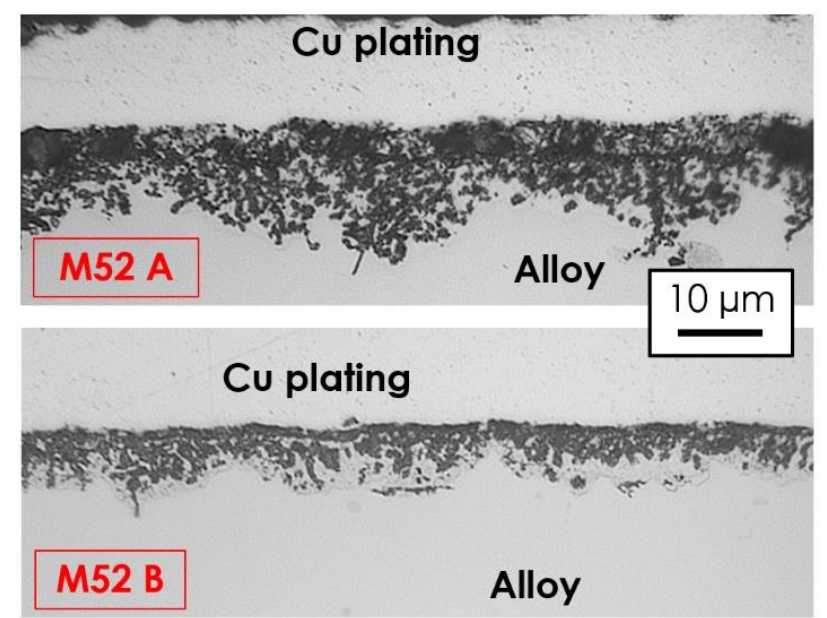

Figure 9. Light micrographs of Alloy M52 cross-sections after exposure to $\mathrm{NaCl}-\mathrm{MgCl}_{2}$ for $500 \mathrm{~h}$ at $700^{\circ} \mathrm{C}$. 


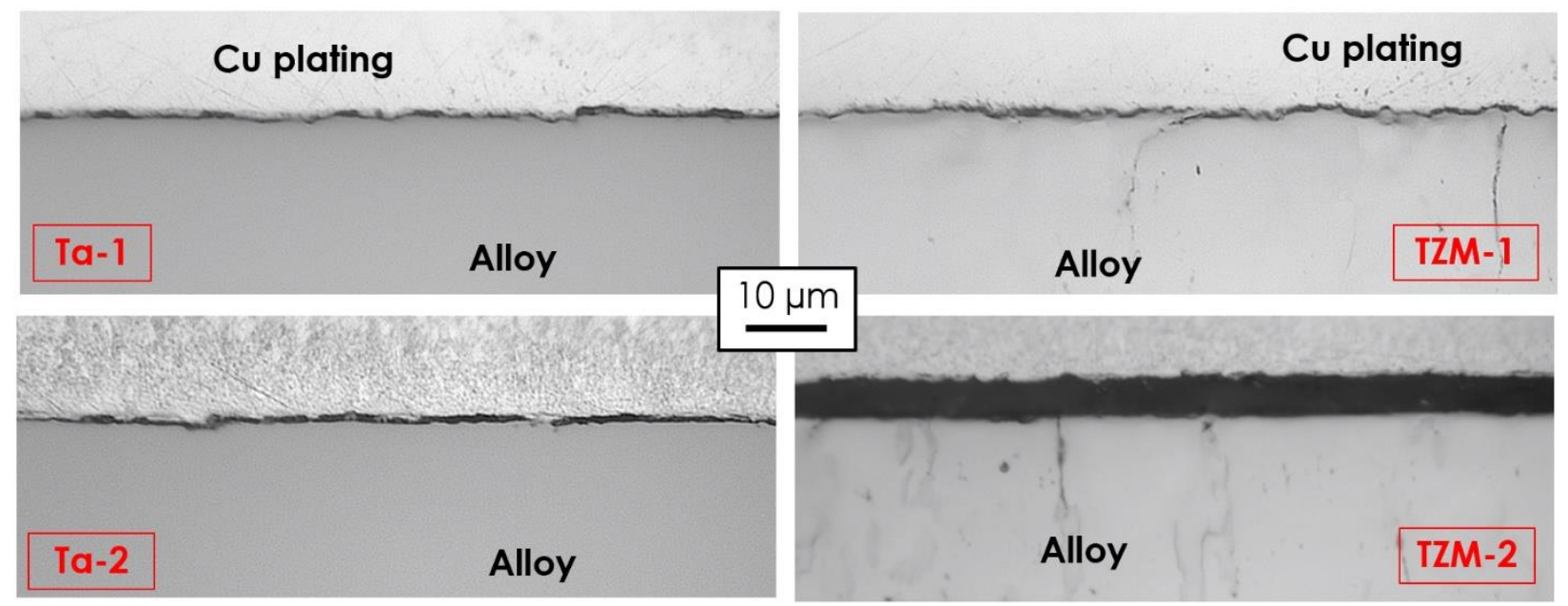

Figure 10. Light micrographs of Tantalum and TZM cross-sections after exposure to NaCl$\mathrm{MgCl}_{2}$ for $500 \mathrm{~h}$ at $700^{\circ} \mathrm{C}$.

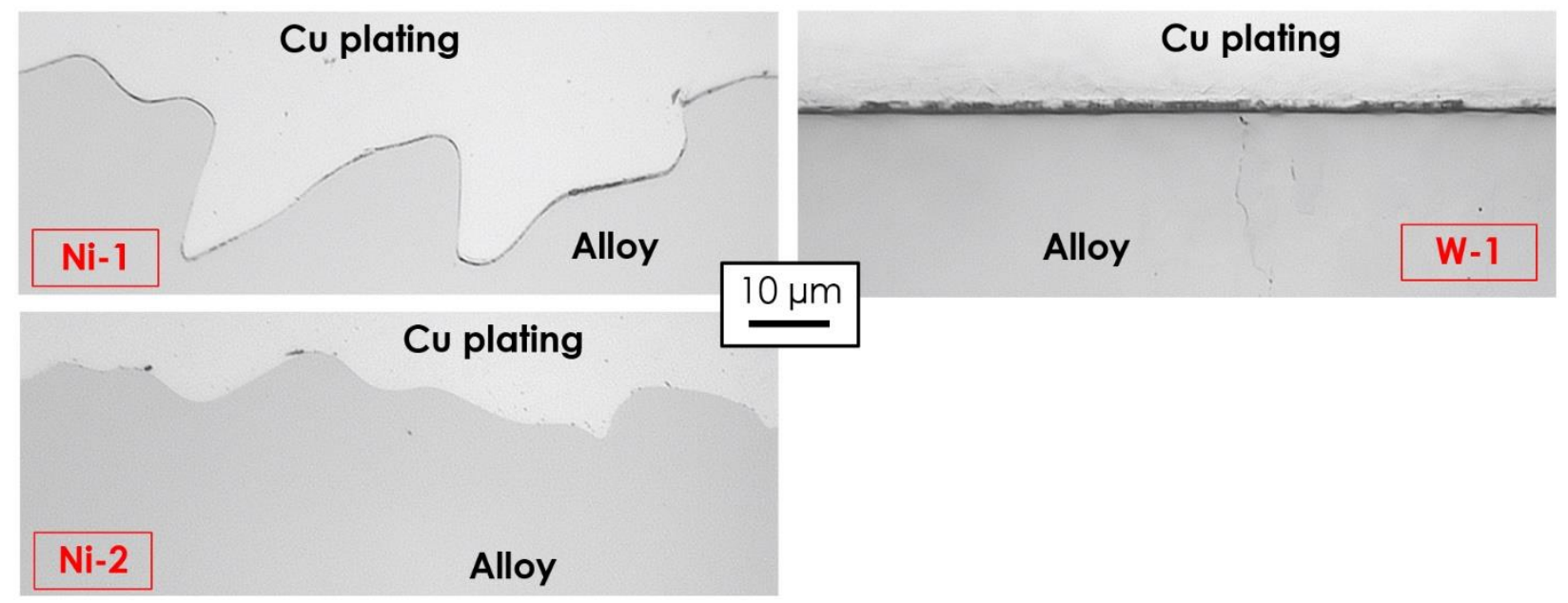

Figure 11. Light micrographs of Ni-200 and Tungsten cross-sections after exposure to NaCl$\mathrm{MgCl}_{2}$ for $500 \mathrm{~h}$ at $700^{\circ} \mathrm{C}$.

\section{CONCLUSIONS}

Tungsten, tantalum, and TZM appear to have very good corrosion resistance in $\mathrm{NaCl}-\mathrm{MgCl}_{2}$. Suitability for use as cladding on salt facing components will depend on testing in flowing salts, as well as weldability, formability, and mechanical properties. Suitability as a core cladding will also depend on radiation tolerance. Nickel-200 showed very poor corrosion resistance, and future work will be necessary to determine why these experiments conflict with thermodynamic predictions. ORNL developed alloys, on average, performed similarly or slightly worse than alloy-N. A full evaluation including flowing salt and mechanical properties will be necessary to determine if they represent an improvement over alloy-N. 


\section{REFERENCES}

1. Koger, J.W., "Evaluation of Hastelloy N Alloy After Nine Years Exposure to Both a Molten Fluoride Salt and At at Temperatures from 700 to 560C (ORNL/TM/4189)" (1972).

2. Keiser, J.R., "Compatibility Studies of Potential Molten-Salt Breeder Reactor Materials in Molten Fluoride Salts (ORNL/TM/5783)" (1977).

3. Manly, W.D., G.M. Adamson, J.H. Coobs, J.H. DeVan, D.A. Douglas, E.E. Hoffman, and P. Patriarca, "Aircraft Reactor Experiment - Metallurgical Aspects (ORNL TM-2349)" (1957).

4. Holcomb, D.E., G. Muralidharan, D.F. Wilson, and D.E. Holcomb, Intermediate Strength Alloys for High Temperature Service in Liquid-Salt Cooled Energy Systems, US009683280B2, 2017.

5. Holcomb, D.E., G. Muralidharan, and D.F. Wilson, Creep-Resistant, Colalt-Free Alloys for High Temperature, Liquid-Salt Heat Exchanger Systems, US009435011B2, 2016.

6. Holcomb, D.E., G. Muralidharan, and D.F. Wilson, High Strength Alloys for High Temperature Service in Liquid-Salt Cooled Energy Systems, UA009540714B2, 2017.

7. Guo, S., J. Zhang, W. Wu, and W. Zhou, Prog. Mater. Sci. 97 (2018): pp. 448-487. 